\title{
Spectroscopic and chemical investigations on volatile fission and activation products within the fuel-cladding interface of irradiated pressurised water reactor fuel rod segments
}

\author{
Tobias König, Ron Dagan, Kathy Dardenne, Michel Herm, Volker Metz, Tim Pruessmann, Jörg Rothe, \\ Dieter Schild, Arndt Walschburger, and Horst Geckeis
}

Karlsruhe Institute of Technology (KIT), Institute for Nuclear Waste Disposal, P.O. Box 3640, 76021 Karlsruhe, Germany

Correspondence: Tobias König (koenig.tobias@kit.edu)

Published: 10 November 2021

\begin{abstract}
In Germany, the present waste management concept foresees the direct disposal of spent nuclear fuel (SNF) in deep geological repositories for high-level waste available by 2050, at best. Until then, SNF is encapsulated in dual-purpose casks and stored in dry interim storage facilities. Licenses for both casks and facilities will expire after 40 years following loading of the cask and emplacement of the first cask in the storage location. Yet, due to considerable delays in the site selection process and the estimated duration for construction and commissioning of a final repository of at least 2 decades, a prolonged dry interim storage of SNF is inevitable (ESK, 2015). Concerning these considerable timespans, integrity of the cladding is of utmost importance regarding the ultimately conditioning of the fuel assemblies for final disposal.

Various processes strain the structural integrity of Zircaloy cladding during reactor operation and beyond such as delayed hydride cracking, fuel-cladding chemical interactions or irradiation damage induced by $\alpha$-emitters present in the fuel pellet's rim zone (Ewing, 2015). Especially with higher burn-up, the gap between fuel and cladding closes and results in the formation of an interaction layer, in which precipitates of fission and activation products are present, displaying an interface for degradation processes.

For chemical analysis and speciation of these agglomerates, Zircaloy-4 and SNF specimens were sampled from fuel rod segments irradiated in commercial pressurised water reactors during the 1980s. Zircaloy-4 specimens were taken from an $\mathrm{UO}_{X}\left(50.4 \mathrm{GWd} \mathrm{t}_{\mathrm{HM}}{ }^{-1}\right)$ and mixed oxide fuel (MOX) $\left(38.0 \mathrm{GWd} \mathrm{t}_{\mathrm{HM}^{-1}}\right)$. In addition, SNF fragments were sampled from the closed gap of both fuel types to examine volatile activation and fission products, which had been segregated from the centre to the pellet periphery during irradiation and thus contribute to the possible chemically assisted cladding degradation effect of the precipitates within the fuel-cladding interface.
\end{abstract}

Spectroscopic analysis of precipitates within the interface layer between fuel and cladding were performed by optical microscopy, X-ray absorption and X-ray photoelectron spectroscopy, as well as by energy-dispersive scanning electron microscopy. Moreover, the radionuclide inventory of the respective Zircaloy- 4 , fuel and interaction layers was determined using liquid scintillation counting, $\gamma$-spectroscopy, gas mass spectrometry, ion chromatography and inductive-coupled plasma mass spectrometry and compared to results received by MCNP/CINDER and webKORIGEN calculations.

In this study, we provide results regarding the speciation and chemical composition of previously identified Cs$\mathrm{U}-\mathrm{O}-\mathrm{Zr}-\mathrm{Cl}-\mathrm{I}$ bearing compounds found in the interaction layer of irradiated nuclear fuel and inventory analyses of radionuclides present therein, with particular emphasis on Cl-36 and I-129. Furthermore, the agglomerates within the fuel-cladding interface were characterised for the first time utilising synchrotron radiation-based $\mathrm{Cl}$ $\mathrm{K}$-edge and I K-edge measurements, resulting in compounds with structural similarities to $\mathrm{CsCl}$ and $\mathrm{CsI}$. The outcomes obtained from this study provide further insights into the complex chemistry within the fuel-cladding interface with respect to the aging management and integrity of SNF under the conditions of interim storage. In 
future studies we will examine whether the different compounds at the fuel-cladding interface have the potential to affect the mechanical properties of Zircaloy cladding.

Kurzfassung. In Deutschland sieht das derzeitige Abfallwirtschaftskonzept die direkte Endlagerung abgebrannter Kernbrennstoffe (SNF [,,spent nuclear fuel“]) in geologischen Tiefenlagern für hochradioaktive Abfälle bestenfalls bis 2050 vor. Bis dahin werden diese SNF in verschlossenen Lagerbehältern in trockenen Zwischenlagern deponiert. Lizenzen für Behälter und Anlagen erlöschen 40 Jahre nach Beladung des Behälters bzw. Einlagerung des ersten Behälters in den Lagerort. Aufgrund erheblicher Verzögerungen bei der Standortauswahl und der voraussichtlichen Dauer für den Bau und die Inbetriebnahme eines Endlagers von mindestens 2 Jahrzehnten ist jedoch eine längere trockene Zwischenlagerung von SNF unumgänglich (ESK, 2015). Angesichts dieser beträchtlichen Zeitspannen ist die Integrität der Umhüllung für die letztendliche Aufbereitung der Brennelemente für die Endlagerung von größter Bedeutung.

Verschiedene Prozesse belasten die strukturelle Integrität der Zirkalloyhülle während des Reaktorbetriebs und darüber hinaus, wie verzögerte Aufspaltung von Hydriden, chemische Wechselwirkungen zwischen Brennstoff und Umhüllung oder durch $\alpha$-Strahler in der Randzone der Brennstoffpellets induzierte Strahlungsschäden (Ewing, 2015). Insbesondere bei höherem Abbrand schließt sich die Lücke zwischen Brennstoff und Mantel, und es bildet sich eine Wechselwirkungszone aus, in welcher sich Ablagerungen von Spalt- und Aktivierungsprodukten befinden, einer Zwischenschicht für Abbauprozesse entsprechend.

Zur chemischen Analyse und Artbestimmungen dieser Agglomerate wurden Zirkalloy-4- und SNF-Proben aus Brennstabsegmenten entnommen, die in den 1980er Jahren in kommerziellen Druckwasserreaktoren bestrahlt worden waren. Zirkalloy-4-Proben stammten aus $\mathrm{UO}_{X^{-}}$(Uranoxid; 50,4 $\mathrm{GWdt}_{\mathrm{HM}^{-1}}{ }^{-1}$ ) und $\mathrm{MO}_{X^{-}}$ Brennelementen $\left(\mathrm{MO}_{X}\right.$ : Mischoxid; 38,0 GWdt thM $\left.{ }^{-1}\right)$. Darüber hinaus wurden SNF-Fragmente aus der geschlossenen Lücke zur Ummantelung beider Brennelementtypen gewonnen, um flüchtige Aktivierungs- und Spaltprodukte zu untersuchen, die während der Bestrahlung vom Zentrum zur Pelletperipherie gelangt waren und somit zum möglichen chemisch unterstützten Manteldegradationseffekt der Ablagerungen innerhalb der Brennstoff-Mantel-Grenzfläche beitragen.

Die spektroskopische Analyse von Präzipitaten innerhalb der Grenzschicht zwischen Brennstoff und Hülle erfolgte mittels optischer Mikroskopie, Röntgenstrahlenabsorption und Röntgenphotoelektronenspektroskopie sowie energiedispersiver Rasterelektronenmikroskopie. Darüber hinaus wurde der Radionuklidgehalt der jeweiligen Zirkalloy-4-, Brennstoff- und Wechselwirkungsschichten mittels Flüssigszintillationszählung, $\gamma$ Spektroskopie, Gasmassenspektrometrie, Ionenchromatographie und induktiv gekoppelter Plasmamassenspektrometrie bestimmt und mit aus MCNP/CINDER- und webKORIGEN-Berechnungen erhaltenen Ergebnissen verglichen.

In dieser Studie liefern wir Ergebnisse zur Bestimmung der Arten und chemischen Zusammensetzung von zuvor identifizierten Cs-UO-Zr-Cl-J-haltigen Verbindungen, die in der Wechselwirkungsschicht bestrahlter Kernbrennstoffe gefunden werden, und Inventaranalysen der darin enthaltenen Radionuklide, mit besonderem Schwerpunkt auf Cl-36 und J-129. Darüber hinaus wurden die Agglomerate innerhalb der Brennstoff-MantelGrenzfläche zum ersten Mal unter Verwendung von synchrotronstrahlungsbasierten Cl-K-Kanten- und J-KKanten-Messungen charakterisiert, was zu Verbindungen mit strukturellen $\mathrm{Ähnlichkeiten} \mathrm{zu} \mathrm{CsCl}$ und CsJ führte. Die Ergebnisse dieser Studie liefern weitere Einblicke in die komplexe Chemie innerhalb der BrennstoffMantel-Grenzfläche in Bezug auf das Alterungsmanagement und die Integrität von SNF unter den Bedingungen der Zwischenlagerung. In zukünftigen Studien werden wir untersuchen, ob die verschiedenen Verbindungen an der Grenzfläche zwischen Brennstoff und Hülle das Potenzial haben, die mechanischen Eigenschaften von Zirkalloyhüllen zu beeinflussen.

Acknowledgements. The authors would like to thank Elke Bohnert, Annika Fried, Markus Fuss, Frank Geyer, Stefanie Kuschel and Cornelia Walschburger (all KIT-INE) for their invaluable analytical work in this study. Volker Krepper, Stefan Schmitt (both KIT-INE) and Gerhard Christill (KIT-SUM) are acknowledged for their contribution to maintenance of the shielded box-line facility and radiation protection work. Furthermore, we would like to thank the KIT Light Source (KARA, Germany) for the provision of the beamtime.

\section{References}

ESK: Diskussionspapier zur verlängerten Zwischenlagerung bestrahlter Brennelemente und sonstiger Wärme entwickelnder radioaktiver Abfälle, Entsorgungskommission, Bonn, Deutschland, 2015.

Ewing, R. C.: Long-term storage of spent nuclear fuel, Nat. Mater., 14, 252-257, 2015. 